UDC [342+342.9+346.1] (477): 341(061.1€C)

DOI https://doi.org/10.32849/2663-5313/2021.10.09

\title{
Liliia Orel,
}

Doctor of Law, Associate Professor, Head of the Department of Public and Private Law at the Faculty of Law and International Relations, Borys Grinchenko Kyiv University, 13B, Tymoshenka Marshala street, Kyiv, Ukraine, postal code 02000, liliia.orel@gmail.com

ORCID: orcid.org/0000-0002-7054-3751

\section{Oleg Baklan,}

Doctor of Law, Professor, Professor at Public and Private Law Department at the Faculty of Law and International Relations, Borys Grinchenko Kyiv University, 13B, Tymoshenka Marshala street, Kyiv, Ukraine, postal code 02000

ORCID: orcid.org/0000-0002-1878-1349

Orel, Liliia, Baklan, Oleg (2021). The administrative and legal impact on the economy and entrepreneurship: comparative legal aspect. Entrepreneurship, Economy and Law, 10, 56-66, doi https://doi.org/10.32849/2663-5313/2021.10.09

\section{THE ADMINISTRATIVE AND LEGAL IMPACT ON THE ECONOMY AND ENTREPRENEURSHIP: COMPARATIVE AND LEGAL ASPECT}

Abstract. Purpose. The issue of state influence on the economy and entrepreneurship is actively discussed in professional and scientific circles of lawyers and economists of any modern country. Ukraine is no exception. Domestic scientists have repeatedly tried to develop considerably significant theoretical and applied recommendations for improving the business climate in our country. During the existence of Ukraine as anindependentstate, theproblems of stateregulationin the field ofeconomy,economicactivity(entrepreneurship in particular) were reflected in the context of research on state influence on the economy, legal regulation of business, implementation of state regulatory policy in business, some legal institutions. administrative law (concerning administrative services, administrative liability, etc.). Some aspects of organizational and legal regulation of economic activity are constantly under the scrutiny of domestic scientists. Despite such strong attention from scholars, lawyers and economists, in Ukraine these aspects are practically not formed and are not provided at the state level. So far, effective principles of state influence on the economy and entrepreneurship have not even been declared, practical forms and methods of its implementation have not been defined and, accordingly, proper effective legal support in this sphere of public life has not been created.

Research methods. The work is performed by applying general scientific and special methods of scientific knowledge.

Results. Analytical and staging consideration of the outlined issues is the purpose of this study. The article is the authors' attempt on the basis of analysis and comparison of foreign experience of state influence in the fields of economics and entrepreneurship to continue and in some aspects introduce a discussion (primarily in administrative law), which would be devoted to finding solutions and solving scientific, applied and practical problems of future development and improvement of the state presence in the field of economy and entrepreneurship of Ukraine.

The article on the example of Germany, Sweden, Finland, France, Great Britain and the United States examines some opinions and views of legal scholars and economists on determining the role of the state in regulating social relations in certain areas of the economy and entrepreneurship. First of all, it is analyzed the administrative and legal impact in certain areas of public life.

Conclusions. Taking into account the analysis, we express our own opinions and considerations on the outlined issues.

Key words: administrative and legal influence, state presence, economy, entrepreneurship, business, economic activity, state regulation, state regulatory policy.

\section{Introduction}

According to the IMF report, Ukraine has been the poorest country in Europe since 2017 (Ukraina stala naibidnishoiu krainoiu Yevropy,
2018). "Ukraine's investment attractiveness index in the first half of 2020 was 2,51 points out of 5 possible and continues to be negative. These are the conclusions of a new wave of expert 
research conducted by the European Business Association. In the previous period, the index was 2,95 points" (Investory pohirshyly otsinku biznes-klimatu Ukrainy, 2020).

Currently, the economic situation in Ukraine, imperfect legal framework for entrepreneurship, corruption, incomes and lack of experience in the proper implementation of investment projects suggest that it is impossible to hope for the implementation of strategically important economic projects without government intervention in today's conditions. Unfortunately, this is confirmed by the contents of the Ukrainian government most programs, which clearly showed a chronic disease of almost all previous domestic government programs declarativeness, lack of clear indicators and key indicators, which will make it difficult to assess the performance of any government (as well as predecessors, etc.), and the first lines of the text of the program "Today Ukraine is in the deepest economic, political and social crisis in the history of its independence. The country is brought to the brink of bankruptcy, society - to a social and humanitarian crisis. The threat of Ukraine's loss of sovereignty and territorial integrity has become real. The country is one step away from financial and economic collapse" are generally questionable, at least because these words were simply copied from the program of the government of Arseniy Yatsenyuk (Ukraina stala naibidnishoiu krainoiu Yevropy, 2018).

Latest research and publications. Today, as in all years of independence, the issue of country influence on the economy and entrepreneurship is actively discussed in professional and scientific circles of lawyers and economists: I. Akimova, O. Belyanevych, J. Zhalilo, O. Zhuravsky, I. Zapatrina, T. Yefimenko, P. Yeshchenko, T. Kolomoyets, A. Krysovaty, O. Ryabchenko, N. Saniakhmetova, D. Stechenko, V. Shcherbyna, etc. At the same time, in Ukraine practically no effective principles of state influence on the economy and entrepreneurship have been formed, ensured, even declared, practical methods and forms of its implementation have not been determined and, accordingly, proper effective legal support in this sphere of public life has not been created.

A consideration of analytical issues is the purpose of this study.

Presentation of basic research material. In the EU member states, there is no common understanding of the concept and scope of Law of the Economy, but the role of Law in regulating the economy is equally understood by all the countries (Saniakhmetova N. O., 1998, p. 87). Today in Europe there is a general trend towards "a whole set of institutional and procedural reforms that allow the EU: to establish a common legal framework and institutional structure for the formation of an area of freedom, security and justice, to put an end to parallel legislation, etc. ..." noted by domestic researchers in international law (Makarukha Z., 2010, p. 193). However, there are other opinions in Ukraine. Thus, a different position is argued by the well-known scholar of commercial law V. Shcherbyna, who also strongly opposes the adoption of the Economic Code in our country, arguing his point of view that the subject of regulation of this Code "cannot be defined, because this subject had to regulate all social relations in the economic sphere, including: administrative, labor, financial, tax, land, environmental, etc." (Shcherbyna V., 2010, p. 15). In general, this is a fair statement.

It is almost universally recognized that administrative and legal interference in the regulation of the economy in general and entrepreneurship in particular is more prevalent in countries with social market economies, which are also declared by Ukraine's political leaders.

2. Some aspects of the state presence in

\section{the German economy}

A striking example of a classic country with a socially oriented market economy is the Federal Republic of Germany. In this country, administrative and legal regulation affects the activities of most businesses and entrepreneurship activities, which produce almost half of the gross product. Under the condition that German statistics take into account only those sectors of the economy in which the level of administrative and legal regulation is the highest, and do not take into account the areas of entrepreneurship that are regulated indirectly.

Individual domestic researchers argue that when referring to the German economy, one should not talk about strengthening state regulation, but about improving the efficiency of state action (Morozov V.S., 2006). It seems to be the right and effective conduct. It is also true that the global goal of state regulation in Germany is specified in the following special tasks:

promoting market organization and market-competitive relations; solution of economic and economic-organizational issues raised by certain influential groups of economic entities; achieving economic, political, social and fiscal goals aimed at maintaining and ensuring market order in the country;

adjusting the allocation of resources in order to influence the economic structure and the structure of the national product.

At the same time, it seems expedient to say that different tasks require different forms of state intervention: on the one hand, direct administrative, and purely economic influence, 
on the other hand. Taking into account everything mentioned above, the system of state regulation can be divided into two levels: market-organizational and financial (Stechenko D. M., 2006, p. 48-49). Organizational and legal support is an external sectoral intervention of public administration bodies in industry, entrepreneurship and freedom of public-private contracts, etc., which is carried out through the refusal of certain branches of social production and enterprises from the general principles of market order in Germany. Thus, "the provisions on public contracts, provided for in paragraphs 54-62 of the Law of Germany "the Administrative Procedure Act", are widely used in the field of construction law, roads, educational law, commercial and administrative law and the law of subventions" (Kuibida R., 2009, p. 81).

As the bearer of the policy of economic and legal influence, the state controls the market behavior of all economic entities. In Germany, the practical result of tripartite negotiations between the government, businesses and trade unions was the basis of a comprehensive national strategy in 2006 - "The High-Tech Strategy" (The High-Tech Strategy for Germany, 2006). One of the main priorities in the development of this act was to identify 17 key technologies that need to be developed, the relationship between science and economics, improving the financing system of economic entities in this area, and so on. In connection with the successful implementation of the High-Tech Strategy for Germany in 2010, the government decided to further implement this project and adopted a new document - "Ideas, innovation, economic prosperity. High-Tech Strategy 2020 for Germany" (Bobrovytskyi A., 2009).

Thus, the evidence from German practice shows that market and organizational regulation is also a form of economic macropolitics.

3. About the Swedish model of regulation of social and market economy

Another example of a classical civilized model of regulation of the social market economy is the Swedish model of regulation. The term "Swedish model" is associated with the formation and strengthening of Sweden in the second half of the twentieth century as one of the most developed countries in the socio-economic aspect, which is characterized by a combination of good governance, political stability, sustainable economic growth, a high level of social protection and a decent level of welfare. The formation and development of the Swedish economic system was not free from the negative effects of global economic crises and recessions, as well as internal socio-economic contradictions. However, the govern- ment has always managed to find an acceptable compromise between the interests of employees and employers, small and large owners, between the need to maintain a high level of employment and wages, on the one hand, and constantly increase the competitiveness of the national economy, on the other hand (Bobrovytskyi A. 2009). At the same time, even in the critical stage of development of the world economy after the crisis of 2008-2009, the Swedish government tried to fulfill a strategic task to avoid unjustified protectionism (Hullhren S., 2009).

In terms of production, Sweden is ahead of most EU countries, its GDP per capita is much higher than the corresponding average for the EU (Bobrovytskyi A., 2009). The essence of state regulation of the Swedish economy is to maximize the production and development of private sector entrepreneurship and the greatest possible redistribution of profits by the state through a progressive tax system and public social infrastructure to improve the living standards of the average population.

It is fascinating that Sweden spends more than $50 \%$ of GDP to finance the state's economic functions and solve a number of social problems (Krysovatyi A. I., Koshchuk T. V., 2009, p. 129). Administrative and legal support in the country can be provided to the least mobile and attractive in terms of entrepreneurship industries, such as ferrous metallurgy, shipbuilding and mining. According to Swedish law, some state-owned enterprises that are designed to perform special state management functions are even monopolies. This applies to such areas of public life as energy, transport, post, and communications (Shvaika L. A., 2008, p. 434-438). Strong state influence in the field of entrepreneurship in Sweden is confirmed by the doctrine of building a socially oriented market economy, which provides for the centralization of about 33\% of GDP only through indirect and personal taxation (Krysovatyi A. I., Koshchuk T. V., 2009, p. 130), which would not be possible without the use of administrative remedies and measures. A feature of the Swedish economy, an important factor in increasing competitiveness is the orientation of the Swedish economy to high technology (the so-called "knowledge economy"). Therefore, large national and multinational companies invest heavily in research and development (R\&D), and the main development is carried out in Sweden (Bobrovytskyi A., 2009).

4. Some aspects of the regulation of the Finnish economy

Finland is a highly developed small industrial country. International recent research shows that Finland is one of the most developed and competitive countries in the world. Its 
advantages are political stability, highly developed infrastructure, accessibility and reliability of telecommunications, freedom of banking competition, well-established system of cooperation between enterprises and universities, including the development of new technologies, high educational level of workforce and management, ease of doing business (Finliandiia).

As in most Western European countries, taxation is the most important instrument of administrative and legal regulation of the economy in Finland. As for the above-mentioned countries, Finland is also characterized by a high level of administrative and legal regulation of the economy and significant state intervention in the field of entrepreneurship. The country's tax system has several direct and indirect taxes. The main direct tax is income tax, utility and property taxes. The most important indirect taxes are sales tax, customs taxes, tax equalization and vehicle excise taxes, excise duties on alcoholic beverages, tobacco and some other goods. At the same time, the Finnish tax authorities have the rights of inquiry and investigation. State-owned and semi-state-owned companies account for $14 \%$ of the total number of large industrial companies in Finland. They provide $35 \%$ of total sales, perform $30 \%$ of export operations, focus on their production $25 \%$ of the workforce (Shvaika L.A., 2008, p. 439). Conditions for doing business in Finland, including legislation, availability of financial resources, state support, lack of bureaucracy and corruption meet all the conditions for increasing the competitiveness of entrepreneurship (Makara O. V., 2007, p. 48).

Among the measures of administrative and legal regulation of entrepreneurship a significant place is occupied by ensuring healthy and effective competition. In Finland, these issues are dealt with by the Finnish Competition Authority under the Ministry of Trade and Industry and the Competition Division, which reports to the provincial governments. In their work, these public bodies are guided by the antitrust law of Finland, the purpose of which is to "protect healthy competition" from the practice of unjustified restrictions. At the same time, within the framework of Finnish legislation, the activities of enterprises are completely independent. Schweik L. A. emphasizes that the state determines only the general conditions of companies through legislation, monetary and credit policy, currency control, taxation, safety rules, environmental regulations, standards, etc. (Shvaika L. A., 2008, p. 440).

5. Experience in regulating the French economy and entrepreneurship

France is one of the few industrialized countries where there is a rather strict regime of state regulation of entrepreneurship, which has survived to this day, as traditionally the mechanism of state regulation of the economy in France has its own history and a variety of economic and administrative and financial instruments. Today, as in the scientific and educational literature, it is noted in the textbook that in these features lies the uniqueness of the French economy, which is often called a hybrid of planned and market approaches. The post-war period, during which the government tried to find the most effective combination of the Keynesian methods of regulation with the development of free enterprise, was quite significant. The main factors that led to the economic transformation of the French economy in the second half of the twentieth century, in particular, were the following.

This increases the presence of the state and state property from $10 \%$ of the value of national property to $40-50 \% \%$ at the beginning of 1980 s. This is the formation of competitive powerful Transnational Corporations (for example, the automobile corporation "Renault") with a high ratio of state share in the share capital structure. However, this approach often proved to be quite burdensome for the French budget, which forced the government to compensate for the damage to the inefficient public sector. As well as high rates of scientific and technological progress and a successful combination of public and private investments aimed at the development of nuclear energy, electrical industry, chemical, pharmaceutical industries, production of aviation and automation equipment. The following factors should also be noted before the administrative and legal impact. Concentration and centralization of industrial and financial capital, significant strengthening of the positions of French firms in international and especially European markets. Clear choice and stimulation of development of branches of national specialization. Unconditional state support for basic and applied research in priority areas of the French economy. Maximum encouragement on a complementary basis for the development of industrial and social infrastructure, the quality of which has largely become exemplary in the European Union (Frantsuzka model ekonomiky, 2005).

For the development of the economy and entrepreneurship, Ukraine should adopt French experience, such as the indicative plan in the country has no directive significance, although adopted by the National Assembly (Parliament). This plan covers a limited number of mandatory tasks and has a more focused, recommendatory nature, in fact, it is a summary of the proposals of various government institutions and non-governmental organizations. 
Ukraine should also take into account that the implementation of the French model of planning and conducting took place at the European level. The current model of the European Commission and other European structures, the development of the current seven-year development plan in the EU, the creation of structural funds and social, regional and agricultural policies are due to the fact that France wants to see European supranational governance systems that are most comparable with the main components of its national model (Frantsuzka model ekonomiky, 2005).

Stimulating the development of competition is an important area of administrative and legal regulation of the market in France. The role of the state is manifested in the organizational and legal aspect in encouraging the development of small enterprises, for example, industrial, family, group, which are assisted in obtaining longterm and short-term government loans, training of management staff, tax benefits, commercial information, etc. (Shvaika L. A., 2008, p. 432). In addition, besides the widespread use of enterprise motivation mechanism in state planning, the state appears as a product customer, owner of works and services.

The French experience clearly confirms the conclusion that the market, whatever its achievements, does not solve many problems (especially in the social spheres and spheres of public life), especially those problems that are caused by the general needs of different population segments and are important for the future of the country.

It should be added that the market does not solve the problems of social protection, does not provide basic, priority research, it is extremely limited in the creation of infrastructure and development of public transport. These and other problems must be solved by the state, using the administrative and legal mechanism for issuing special government orders to manufacturers, which are a priority for many companies, because in conditions of fierce competition in the market they ensure constant investment, profit and social results. It is also possible to directly stimulate government procurement through preferential pricing, taxation and lending.

In other words, France is developing a branched social sector and at the same time trying to flatten structural maladjustments of the economy through budget interventions (Krysovatyi A. I., Koshchuk T. V., 2009, p. 128). Therefore, the indicative plan is of great importance for the administrative-territorial units of France (which is important to consider for Ukraine in terms of the development of decentralization policy). When it is approved by parliament, it becomes a guide for concluding public-private agreements with regions, departments and communes on the material and financial aspects of their development, including subsidies and grants from the central budget. This is a positive example of concluding administrative and legal agreements between various public administration bodies, business entities, etc. The nature of fiscal policy directly depends on the indicative plan: the more subsidies - the less need to attract their own financial resources and vice versa.

Today, the closer convergence of national markets of countries with developed market relations has forced the transition from indicative planning to strategic planning. Its essence is to choose the main priorities for the development of the national economy, the leading role in the implementation of which should be played by the country. Due to strategic planning it is determined the ways in which society should go, decide which markets are best to operate, which technology to master first, how to ensure the social unity of the country, which sector of the economy and social structures should be relied on (Stechenko D. M., 2006, p. 47).

Thus, the essence of strategic planning in France is to choose the main priorities of the national economy, the leading role is played by the country, which is trying to decisively influence the definition of the main directions of social relations in the economy and domestic entrepreneurship, etc.

6. State presence in the British economy

Great Britain, like France, as well as other industrialized nations in general, significantly strengthened some forms of state regulation of the economy after the end of World War II. The main reason for this, at least initially, regardless of the types of regulation introduced, was the protection or promotion of the public interest. Many public funds that regulate the production and sale of food and medicine are aimed at this. Research on dominant market positions and the prevention of significant mergers of companies are aimed at supporting competition and promoting effective economic development. After the Second World War, the number of laws governing the economy in the UK has grown significantly and remains so today (Saniakhmetova N. O., 1998, p. 87-88). Even the adoption in the second half of the twentieth century of forms and rigid methods of regulation inherent in Thatcher's government did not lead to a "return to a lower level of government," as promised by the prime minister. Neoliberal model of state regulation in the UK has extended its influence to utilities and other sectors of the economy (Pabst A., 2010, p. 47).

Thus, the United Kingdom, especially London, has traditionally been the world's financial center. The United Kingdom has an extremely independent, developed and international trade econ- 
omy. In the United Kingdom, according to both domestic and foreign scientists (Stechenko D. M., 2006; Utton M. A., 1986), there was no period when the economy could function freely from state regulation of one kind or another, although its distribution and direction changed.

In the past, there were more foreign banks in London than in any other city in the world, although it is not yet known whether this tendency persists after Brexit. Increased competition and technological developments have accelerated changes of an administrative nature. Thus, the International Stock Exchange was reorganized and the historic two-tier structure of brokers and speculators was abolished. Brokers followed the instructions of investors to buy and sell shares and stocks, and speculators "created" markets for these securities. As a result, the new companies link British and foreign banks with former brokers and jobbers. These new financial institutions are governed by the Financial Services Act 1986, the Construction Companies Act 1987, and the Banking Act 1987.

In 1997, the government established the Financial Services Authority (FSA) to regulate the financial services industry, making some organizational changes. Namely, the government has replaced a number of separate oversight organizations, some of which now operate on a self-regulatory basis. Among other tasks, the FSA has taken over the administrative supervision of commercial banks in the United Kingdom from the Bank of England. The FSA was acting on the basis of protectionism, and due to this it was widely criticized for its response to the financial crisis that erupted in 2008 and which led to forced state financial assistance to a number of well-known British banks. As a result, the Financial Services Act 2012 repealed the FSA, and the "tripartite" system of financial regulation (FSA, the Bank of England and HM Treasury) was replaced in 2013 by three new bodies - the Financial Conduct Authority (FCA), the Financial Policy Committee (FPC) and the Prudential Regulation Authority (PRA). FPC and PRA were structured in the Bank of England, that was returned to the administrative functions of supervision and regulation of banks (United Kingdom - Economy, 2020). Administrative and legal impact on the economy in the UK, primarily related to such institutions as: economic database; financial incentives, prices and incomes, credit, foreign trade; monopolies and mergers; regulation of market behavior, consumer protection, intellectual property, environmental control. At the same time, the administrative and legal regulation of entrepreneurship is primarily used in such sectors of the economy as agriculture, fisheries, energy, and transport.
There are a number of organized financial markets in the United Kingdom. Securities markets include the International Stock Exchange, which trades officially registered shares; an Over-theCounter (OTC) securities market for small companies; and the Third Market for small unlisted companies. Money market activities include trading in promissory notes, certificates of deposit, short-term deposits and, increasingly, trading securities in pounds sterling. Other markets are markets that trade in Eurocurrency, Eurobonds, foreign currency, financial futures, gold, shipping brokerage operations, freight futures, and futures on agricultural and other commodities (United Kingdom - Economy, 2020).

We believe that economic growth in the UK is not least due to the stability of the financial and tax system. And this despite the fact that over the past few decades the economy and entrepreneurship in the country have been nationalized and denationalized, prices and incomes have been subject to mandatory voluntary control, attempts have been made to control industrial relations through legislative restrictions, "gentlemen's agreements" and etc. (Kozyryn A. N., 2011).

In other words, in the United Kingdom, selective administrative and legal intervention of the state in the economy is not accidental and short-term. Attempts are made here to encourage the development of certain industries, entrepreneurship, and so on. In the United Kingdom, there are clear administrative and legal mechanisms and relevant units in government business support bodies that deal with the placement of government orders in small businesses on a competitive basis.

In addition, there is a system of subcontracting, which allows large enterprises to transfer part of the orders to small enterprises. Intervention at the micro level has become a major part of the state economic strategy (Saniakhmetova N. O., 1998, p. 88). Currently, the United Kingdom conducts a fairly active budget financing of economic (related to the development of infrastructure and capacity building of certain sectors of the economy) and social programs (Krysovatyi A. I., Koshchuk T. V., 2009, p. 128).

7. On government intervention in the US economy

Government intervention in the economy is a constant rule in the history of the United States, that is the most developed country in North America (Audretsch, David B., 1989, p. 9). The state as person in state regulatory agencies (analogues of Civil Services, inspections, agencies in Ukraine) has a strong influence on the economy, which operates in the microstructures of the economy (Brody E. David, 1986, p. 3).

Strengthening the presence of the state in the United States is reflected in the signifi- 
cant expansion of direct regulation of economic life, expanding the scope of state control, and in the United States new activity categories fall under state control (Samuelson Pol, 2000 , p. 278, 286, 302). The United States actively uses the fiscal potential of personal tax, does not significantly expand the limits of social taxation, follow a strategy of moderate fiscal efficiency of corporate tax and does not avoid the development of property taxation. Unlike Western Europe, the United States does not consider it appropriate to set significant fiscal targets for the taxation of consumption processes. This tax structure indicates the desire of this country to fix the main tax burden on relatively well-off strata of society and at the same time create a favorable tax environment for entrepreneurship as a prerequisite for GDP growth (Krysovatyi A. I., Koshchuk T. V., 2009, p. 130).

Researchers of macroeconomic regulation of US entrepreneurship admit that until the economic and financial crisis of 2008-2010, the US market regulation mechanism was considered the most developed, because neither direct nor indirect government intervention in the economy caused undesirable deformation of the mixed economy. The functioning of the US economy is based on the "supply economy", which is characterized by the idea of the central role of the market. The state regulates the management relations of enterprises, at the same time ensures their freedom, encourages honest business activity and punishes those who ignore the rights and interests of market participants. US market self-regulation is complemented by state and is formed into a mechanism of purposeful macroeconomic regulation. All this benefits domestic entrepreneurship (Rechmen D. D., Meskon M. C., Bouvy K. L., Tyll D. V., 1995, p. 359-360).

Throughout the long history of the United States government agencies still perform numerous functions to control economic activity: issue laws against tax evasion and fictitious entrepreneurship, exercise customs control, regulate the activities of public and rail transport, monitor the implementation of labor and social security laws, set the minimum and maximum prices, regulate public works, national defense, national and local taxation, provide a minimum wage (Martin T. Farris, 1978, p. 307-312). According to the American historian A. Brinkley, in the most difficult times for US entrepreneurship, the Government intensifies its intervention in the regulation of certain sectors of the economy to prevent negative phenomena, while playing a crucial role (Brinkley A., 1997, p. 920).

Among the measures and means of administrative and legal regulation of the US market, an important place has always been occupied by the programming of the economy, which covered the development and implementation of federal and regional programs. Administrative and legal regulation of the US economy makes extensive use of monetary policy, including government procurement policy. Due to government orders, such sectors of the US economy as the nuclear, aerospace, electric power, and other industries were practically created. In the regulation of managerial relations in the United States a prominent place is occupied by fiscal policy, which is to establish a regime of state taxation and public spending, when they help to dampen economic fluctuations, promote high employment, limit inflation or mitigate stagnation (Louis Hartz, 1948, p. 362).

Direct and indirect state intervention in the economic life of the United States is based on a system of theoretically sound and proven in economic practice universal methods and leverages. It is not aimed at deforming or eliminating the system of private enterprise, the competitive environment, the foundations of a mixed economy, etc. At the same time, having the most powerful scientific and technological potential among developed countries, the United States is trying to maintain its position as a leading country. According to the American scientist M. Weidenbaum (Weidenbaum L. Murray, 1995, p. 46), the general trend of business regulation is one that continues on its upward trajectory. Both corporations and the US federal government attach great importance to the further progress of the information sector of the economy. According to American experts, efficient and effective telecommunications not only play a crucial role in the information competence of the nation, but also serve as a driving force for the growth of national wealth and, consequently, its economic potential (Shvaika L. A., 2008, p. 441).

On the example of the United States, the Ukrainian-Canadian scientist N.O. Saniahmetova. In her opinion (which we fully share), according to the ideals of classical laissez-faire capitalism, the US economy is characterized as a "mixed" system. The state has a strong influence on the economy, penetrates into the microstructure of the economy and the functioning of a successful economic system. Although, private entrepreneurs make most decisions at their own discretion, their scope is reduced, and accordingly the sphere of state influence increases (Saniakhmetova N. O., 1998, p. 95).

\section{Conclusions}

Taking into account the above, it is worth agreeing with the conclusions that highlight the most similar features in the foreign experience of administrative and legal influence of the state on the economy, as follows:

Firstly, the most significant of these features is the focus on the efficiency of the economy and market forces, when the degree and form 
of state influence were mainly dictated by what best promotes competition in the market. This is a manifestation of international competition in most commodity markets in the world, which has an impact on public policy. In market economies, where market mechanisms and state intervention should be minimal, there is a need to use state influence in case of market failures or imperfections, in particular, the existence of monopolies, the weakness of small businesses, structurally weak industries, etc., which cause and require state aid and to some extent administrative and legal interference. Market economies have taken a variety of measures to help certain sectors of the economy, regulate the behavior of entrepreneurs, and sometimes participate in business Typical state intervention in the economy was carried out in the form of regulation through the activities of government agencies. State regulation is justified where the free market system is unable to function effectively (for example, in the areas of consumer protection; labor protection; for the rational use of natural resources) (Saniakhmetova N. O., 1998, p. 88).

Secondly, today modern international economic relations cannot be limited exclusively to power relations between states; An important place in their system is occupied by transnational relations between non-governmental actors. As a basic system of social relations, international economic relations are regulated not only by international economic law, but also by other branches and institutions of international law (Tolochko O. N., 2013).

Thirdly, analyzing the theories of state influence on the economy and entrepreneurship, it is appropriate to take into account the fact that: "Since the regulation of the economy takes many different forms and affects by various means, it is clear that there is no single explanation of its causes and possible positive effects on the economy. State regulation of a market economy in all its manifestations covers such a large number of markets for goods and services and differs so significantly in form and volume that one theory is difficult to explain at least some of regulation cases" (Saniakhmetova N. O., 1998, p. 84-85).

These findings indirectly confirm the well-chosen data of expert economist V. Novikov which cover all the stories of economic success over the past 70 years, namely: 13 cases where during the life of one generation of GDP per capita has grown at least four times, which demonstrates the researcher-economist in the following table 1 :

From this table follows another simple and obvious conclusion, which is also useful for

Table 1

\begin{tabular}{|c|c|c|c|}
\hline Country & The period & GDP & Political regime and ideology in the country \\
\hline Botswana & $1960-2007$ & 18 & $\begin{array}{l}\text { Multi-party liberal democracy but, in fact, a one-party system. The } \\
\text { whole period of growth in power was one party, all presidents were its } \\
\text { members. Resource-based economy(diamonds). }\end{array}$ \\
\hline Brazil & $1950-1980$ & 4 & $\begin{array}{l}\text { 1951-1954: the fascist regime of Vargas, 1956-1964: the democratic } \\
\text { regime, 1964-1980: the power of military dictators. }\end{array}$ \\
\hline Hong Kong & 1960-1997 & 10 & British colony. \\
\hline Indonesia & $1966-1997$ & 5 & $\begin{array}{l}\text { Dictatorial regime with official anti-communist ideology, periodic } \\
\text { changes in the economic policy of neoliberalism and nationalism. The } \\
\text { collapse of the neoliberal economy in } 1997 \text {. }\end{array}$ \\
\hline China & $1978-2019$ & 24 & $\begin{array}{l}\text { One-party authoritarian system with official communist ideology, in } \\
\text { practice - economic nationalism. }\end{array}$ \\
\hline Japan & $1950-1983$ & 11 & $\begin{array}{l}\text { Multi-party constitutional monarchy, but the whole period of growth } \\
\text { in power was one party. }\end{array}$ \\
\hline South Korea & $1960-2001$ & 12 & $\begin{array}{l}\text { Until } 1987 \text { - authoritarian military rule. The first civilian president } \\
\text { was elected in 1992, and a liberal-democratic regime has now been } \\
\text { established. }\end{array}$ \\
\hline Malaysia & $1967-1997$ & 6 & $\begin{array}{l}\text { A multiparty constitutional monarchy, but throughout the period } \\
\text { of growth in power there was one coalition led by the Malay National- } \\
\text { ist Party. }\end{array}$ \\
\hline Malta & 1963-1994 & 9 & $\begin{array}{l}\text { Parliamentary democracy - in fact, bipartisan. During the period } \\
\text { of growth, the economic policies of both parties were nationalistic. }\end{array}$ \\
\hline Oman & 1960-1999 & 9 & $\begin{array}{l}\text { Absolute monarchy of the medieval type (sultanate). Resource-based } \\
\text { economy (oil). }\end{array}$ \\
\hline Singapore & $1967-2002$ & 27 & $\begin{array}{l}\text { Formally - a multiparty democracy, in fact - a one-party authori- } \\
\text { tarian regime. During the period of growth, the head of government } \\
\text { changed only once - in } 1990 .\end{array}$ \\
\hline Taiwan & $1965-2002$ & 11 & $\begin{array}{l}\text { Almost the entire period of growth in power was one party ("The Kuo- } \\
\text { mintang"), which ideology is a mixture of nationalism and socialism. } \\
\text { Until 1987, martial law has been declared. }\end{array}$ \\
\hline Thailand & 1960-1997 & 7 & Most of the period of growth took place under a military junta. \\
\hline
\end{tabular}


Ukraine: economic growth does not depend on the ideology of the ruling political force, it can be equally successfully provided by communists, anti-communists, nationalists and even just military dictators who cared (which is important - the authors' note) economic growth (Novykov V., 2019), in particular, through investments of any origin (excluding, of course, criminal sources).

Thus, as a general conclusion, it can be argued that in foreign experience of administrative and legal influence of the state on the economy and entrepreneurship, the most characteristic feature to be considered in Ukraine is the fact that any regulation is justified where the free market system, unable to function effectively.
Accordingly, the use of legal regulation of the economy and entrepreneurship as a kind of state regulation depends on the specific area (direction) of regulation and is justified in cases where the degree and form of legal influence on the economy and entrepreneurship is justified by the fact that this influence best promotes competition.

It is also worth supporting the proposal of domestic young researchers to develop and implement a strategy for the development of high-tech industries (Chubenko V., 2019), which can be an impetus not only to the conceptual proclamation by the state of the need to develop high-tech industries, as well as to initiate effective and systematic measures of hightech products.

\section{References:}

Ukraina stala naibidnishoiu krainoiu Yevropy (2018) - dani MVF: elektronne vydannia. URL: https://www.epravda.com.ua/news/2018/10/12/641571 (in Ukrainian).

Investory pohirshyly otsinku biznes-klimatu Ukrainy (2020). UKRINFORM 25.09.2020 : elektronne vydannia. URL: https://www.ukrinform.ua/rubric-economy/3056435-investori-pogirsili-ocinku-biznesklimatu-ukraini.html (in Ukrainian).

Saniakhmetova N. O. (1998) Rehuliuvannia pidpryiemnytskoi diialnosti v Ukraini (orhanizatsiino-pravovi aspekty): dys. ... dokt. yuryd. nauk: 12.00.07. Odesa. 403 p. (in Ukrainian).

Makarukha Z. (2010) Pravove rehuliuvannia rozvytku svobody, bezpeky ta yustytsii v ramkakh YeS: reformy Lisabonskoho dohovoru 2007 roku. Pravo Ukrainy. № 11. P. 188-193 (in Ukrainian).

Shcherbyna V. (2010) Deiaki problemy hospodarskoho i hospodarskoho protsesualnoho zakonodavstva. Pravo Ukrainy. № 8. P. 13-19 (in Ukrainian).

Morozov V.S. (2006) Derzhavne rehuliuvannia nimetskoi ekonomiky v umovakh finansovoekonomichnoi kryzy: Teoretychni ta prykladni pytannia ekonomiky: elektronne vydannia. № 25 . URL: http://tppe.econom.univ.kiev.ua/data/2011 25/zb25 17.pdf (in Ukrainian).

Stechenko D. M. (2006) Derzhavne rehuliuvannia ekonomiky : [navch. posib.]. 3-tie vyd., vypr. K. : Znannia, 262 p. (in Ukrainian).

Kuibida R. (2009) Problema administratyvnoho dohovoru u doktryni zakonodavstva ta praktytsi. Pravo Ukrainy. 2009. № 3. P. 76-85 (in Ukrainian).

The High-Tech Strategy for Germany. (2006) Berlin : Federal Ministry of Education Research. 111 p (in English).

Ideas. Innovation.Prosperity. (2020) High-Tech Strategy 2020 for Germany.Bonn:BMBF.2010.26 p (in English).

Bobrovytskyi A. (2009) "Shvetska model": styslyi ohliad stanovlennia, zdobutkiv i problem. TsENTR RAZUMKOVA. NATsIONALNA BEZPEKA I OBORONA. №1, 2009: elektronne vydannia. URL: https://razumkov.org.ua/uploads/journal/ukr/NSD105 2009 ukr.pdf (in Ukrainian).

Hullhren S. (2009) Shvetsiia ta Ukraina: partnerstvo zarady maibutnoho. TsENTR RAZUMKOVA. NATsIONALNA BEZPEKA I OBORONA. №1, 2009: elektronne vydannia. № 25. URL: https://razumkov.org.ua/uploads/journal/ukr/NSD105_2009_ukr.pdf (in Ukrainian).

Krysovatyi A. I., Koshchuk T. V. (2009) Podatkova harmonizatsiia ta natsionalni osoblyvosti opodatkuvannia vysokorozvynutykh krain. Ekonomika i prohnozuvannia. 2009. № 4. P. 126-139 (in Ukrainian).

Shvaika L. A. (2008) Derzhavne rehuliuvannia ekonomiky: [pidruch.]. K. Znannia. 462 p. (in Ukrainian).

Finliandiia. elektronne vydannia: http://www.export-ugra.ru/Putevoditel_Finlandiya.pdf (in Russian).

Makara O. V. (2007) Konkurentospromozhnist ekonomichnoho seredovyshcha v Ukraini. Porivnialnyi analiz reitynhiv okremykh krain. Ekonomika i prohnozuvannia. 2007. № 2. P. 43-56 (in Ukrainian).

Frantsuzka model ekonomiky. (2005) Ekonomika zarubizhnykh krain : elektronne vydannia. URL: https://library.if.ua/book/105/7333.html (in Ukrainian). 
Pabst A. (2010) The Crisis of Capitalist Democracy. Telos. Fall 2010. P. $44-67$ (in English).

Utton M. A. (1986) The Economics of Regulating Industry. Oxford: Basic Black-well, 243 p.: elektronne vydannia: http://www. economyprofessor.com/economictheories/regulation.php (in English).

United Kingdom - Economy (2020) https://www.britannica.com/place/United-Kingdom/ Economy (in English).

Kozyryn A. N. (2011) Fynansovo-pravovye aspekty pryvatyzatsyy. Vystuplenye na plenarnom zasedanyy Mezhdunarodnoi nauchno-praktycheskoi konferentsyy «Fynansovoe pravo v KhKhI veke: dostyzhenyia y perspektyvy», 05.10.2011. Yrpen: NYY fynansovoho prava NUHNS Ukrayny (in Russian).

Audretsch, David B. (1989) The Market and the State: Government Policy towards Business in Europe, Japan, and the USA. New York: University Press, 325 p (in English).

Brody E. David. (1986) Business and Its Legal Environment. Lexington: D. C. Heath and Company. 857 p (in English).

Samuelson Pol. (2000) Ekonomyka: [ucheb. posob. / Pol Samuelson; per. s anhl. pod red. N. V. Shulpynoi]. 16-e yzd. SPb.; K.; M.: Yzd. dom «Vyliams». 680 p (in Russian).

Rechmen D. D., Meskon M. C., Bouvy K. L., Tyll D. V. (1995) Sovremennui byznes. M.: Respublyka. T. 2. 479 p (in English).

Martin T. Farris. (1978) The Case against Deregulation in Transportation Power and Communications. ICC Practitioners Journal 45. P. 307-312 (in English).

Brinkley A. (1997) The Unfinished Nation: A Concise History of the American People. Second Edition. N.Y. : The McGrow Hill Companies, Inc. 1152 p (in English).

Louis Hartz. (1948) Economic Policy and Democratic Thought-Cambridge, Mass. Harward University Press, 1948. 252 p (in English).

Weidenbaum L. Murray. (1995) Business and Government in the Global Marketplace. New Jersey : Prentice Hall, 1995. 823 p (in English).

Tolochko O. N. (2013) Mezhdunarodnoe эkonomycheskoe pravo y ymplementatsyia eho norm v natsyonalnuiu pravovuiu systemu: na prymere Respublyky Belarus: avtoref. dys. na soysk. nauk. stepeny doktora yurydycheskykh nauk: 12.00.10: Sankt-Peterburh. 39 p (in Russian).

Novykov V. (2019) O huru ekonomiky: kuda zavedut stranu neolyberaly: elektronne vydannia. URL: https://www.epravda.com.ua/rus/columns/2019/08/29/651055 (in Russian).

Chubenko V. (2019) Deiaki pytannia pravovoho rehuliuvannia hospodarskoi diialnosti shchodo vyrobnytstva ta postachannia vysokotekhnolohichnoi produktsii v Ukraini. Pidpryiemnytstvo hospodarstvo ta pravo: elektronne vydannia. 2019. № 4. URL: http://pgp-journal.kiev.ua/ archive/2019/4/18.pdf (in Ukrainian).

\section{Лілія Орел,}

доктор юридичнихнаук, доиент, завідувач кафедри публічного та приватного права факультету права та міжнародних відносин, Київський університет імені Бориса Грінченка, вул. Маршала Тимошенка, 13Б, Київ, Україна, індекс 02000, liliia.orel@gmail.com

ORCID: orcid.org/0000-0002-7054-3751

\section{Олег Баклан,}

доктор юридичних наук, професор, професор кафедри публічного та приватного права факультету права та міжнародних відносин, Київський університет імені Бориса Грінченка, вул. Маршала Тимошенка, 13Б, Київ, Україна, індекс 02000, olegvb8888@ukr.net

ORCID: orcid.org/0000-0002-1878-1349

\section{ПРО АДМІНІСТРАТИВНО-ПРАВОВИЙ ВПЛИВ НА ЕКОНОМІКУ ТА ПІДПРИЕМНИЦТВО: ПОРІВНЯЛЬНО-ПРАВОВИЙ АСПЕКТ}

Анотація. Проблематика державного впливу на економіку й підприємництво активно обговорюється у професійних і наукових колах юристів та економістів будь-якої сучасної країни. Не є винятком із цього Україна. Такі відомі вітчизняні вчені, як І. Акімова, О. Беляневич, Я. Жаліло, О. Журавський, І. Запатріна, Т. Єфименко, П. Єщенко, Т. Коломоєць, А. Крисоватий, О. Рябченко, Н. Саніахметова, Д. Стеченко, В. Щербина, неодноразово намагалися виробити значущі теоретико-прикладні рекомендації щодо оздоровлення бізнес-клімату в нашій країні. За часів існування України як незалежної держави проблеми державного регулювання у сфері економіки, господарської діяльності (зокрема, підприємництва) отримували відображення в контексті наукових дослі- 
джень державного впливу на економіку, правового регулювання підприємницької діяльності, реалізації державної регуляторної політики в бізнесовій сфері, окремих правових інститутів, насамперед адміністративного права (щодо адміністративних послуг, адміністративної відповідальності тощо). Окремі аспекти організаційно-правового регулювання господарської діяльності постійно перебувають під пильною увагою вітчизняних науковців. Це зокрема, стосується деяких праць О. Вінник, Т. Кравцової, В. Крикуна, В. Опришка, В. Нагребельного, А. Омельченка, С. Петрова, С. Познякова, В. Полатая, О. Харитонової, С. Чистова, В. Фещенка, Л. Швайки та багатьох інших дослідників. Незважаючи на таку потужну увагу з боку вчених-юристів та економістів, в Україні на державному рівні практично не сформовані, не забезпечені, навіть не задекларовані дієві принципи державного впливу на економіку й підприємництво, не визначені практичні форми та методи його здійснення, а отже, не створене належне дієве правове забезпечення в цій сфері суспільного життя. Аналітичнопостановочний розгляд окреслених питань і становить мету дослідження.

Методи дослідження. Роботу виконано на підставі загальнонаукових і спеціальних методів наукового пізнання.

Результати. Стаття є спробою авторів на підставі аналізу та порівняння закордонного досвіду державного впливу у сферах економіки і підприємництва продовжити, а в окремих аспектах (насамперед в адміністративно-правовій науці) запровадити дискусію, яка була би присвячена пошуку шляхів розв’язання та вирішенню науково-прикладних (а можливо, і практичних) проблем майбутнього розвитку й удосконалення державної присутності у сфері економіки та підприємництва України. У статті на прикладі Німеччини, Швеції, Фінляндії, Франції, Великої Британії та США розглядаються окремі думки вчених-юристів та економістів щодо визначення ролі держави в упорядкуванні суспільних відносин у сферах економіки та підприємництва, а також аналізується адміністративно-правовий вплив в окремих галузях суспільного життя.

Висновки. 3 урахуванням зробленого аналізу автори висловили власні міркування з окреслених питань та надали пропозиції щодо покращення ситуації в розглядуваній сфері.

Ключові слова: адміністративно-правовий вплив, бізнес, господарська діяльність, державне регулювання, державна регуляторна політика, державна присутність, економіка, підприємництво.

The article was submitted 18.10.2021

The article was revised 08.11.2021

The article was accepted 29.11.2021 